Omni-Akuatika, 16 (1): 1 - 10, 2020
ISSN: 1858-3873 print / 2476-9347 online
Research Article
journal homepage: http://ojs.omniakuatika.net

\title{
Efficacy of GP-11 KHV DNA Vaccine in Common Carp (Cyprinus carpio) through Feed by Different Frequency of Administration
}

\author{
Ahmad Beni Rouf ${ }^{1}$, Sri Nuryati ${ }^{2}$, Alimuddin Alimuddin ${ }^{2}$ dan Sukenda Sukenda ${ }^{2}$ \\ ${ }^{1}$ Master Student of Aquaculture Science, Graduate School of IPB University, Bogor, West Java, Indonesia \\ ${ }^{2}$ Departement of Aquaculture, Faculty of Fisheries and Marine Science, IPB University, Bogor, West Java, \\ Indonesia \\ ‘Corresponding author: sri.nuryati606@gmail.com
}

Received 5 December 2019 ; Accepted 17 July 2020 ; Available online 31 May 2020

\begin{abstract}
GP-11 KHV DNA vaccine is a vaccine that can be used to induce immunity against the KHV virus (Koi herpesvirus). Vaccination through feed is an alternative way of administering vaccines. KHV DNA vaccine research through feed was previously using a GP-25 KHV DNA whole cell vaccine with a frequency of 3 times for 7 days resulted in an RPS of $84 \%$. The study aimed to examine the effect of giving GP-11 KHV DNA vaccine through feed with different frequencies to KHV infection compared to GP-25 KHV DNA Vaccine. The frequency of vaccine administration is GP-11 vaccination once a week; GP-11(1x), GP-11 vaccination twice a week; GP-11(2x), GP-11 vaccination three times a week; GP11(3x), GP-25 vaccinations three times a week; GP-25(3x), negative control (without KHV test) and positive control (KHV tested). The fish were kept for 28 days after vaccination and then continued with the KHV challenge test for 28 days. The weight of carp ranges from $13.82 \pm 2.37 \mathrm{~g}$ maintained with a density of 15 fish/aquarium. The results showed that vaccine treatment was able to induce an immune response as indicated by the number of white blood cells, lysozyme activity and post-vaccination antibody titer showed a significant effect compared to controls. Likewise after the challenge test, supported by IFN $\gamma$ and IgM gene expression parameters after the challenge test showed the highest value of vaccine treatment rather than control. The efficacy of vaccine was showed by RPS value (\%) in each vaccine treatment obtained GP-11(1x) value of $44.7 \pm 3.7 \mathrm{a}, \mathrm{GP}-11$ (2x) of $78.9 \pm 18.2 \mathrm{~b}, \mathrm{GP}-11$ (3x) $85.6 \pm 12.6 \mathrm{~b}$ and GP-25(3x) $79.5 \pm 18.1 \mathrm{~b}$. It was concluded that administering the GP-11 vaccine frequency 2 times a week provides protection as strong as giving a vaccine frequency 3 times a week.
\end{abstract}

Keywords: common carp, DNA vaccine, frequency of administration, koi herpesvirus

\begin{abstract}
ABSTRAK
Vaksin DNA GP-11 KHV adalah vaksin yang dapat digunakan untuk menginduksi kekebalan terhadap virus KHV (Koi herpesvirus). Vaksinasi melalui pakan adalah cara alternatif pemberian vaksin. Penelitian vaksin DNA KHV melalui pemberian makanan sebelumnya menggunakan vaksin GP-25 KHV DNA sel keseluruhan dengan frekuensi 3 kali selama 7 hari menghasilkan RPS sebesar $84 \%$. Penelitian ini bertujuan untuk menguji pengaruh pemberian vaksin DNA GP-11 KHV melalui pakan dengan frekuensi yang berbeda terhadap infeksi KHV dibandingkan dengan Vaksin DNA GP-25 KHV. Frekuensi pemberian vaksin adalah vaksinasi GP-11 seminggu sekali; GP-11 (1x), vaksinasi GP-11 dua kali seminggu; GP-11 (2x), vaksinasi GP-11 tiga kali seminggu; GP-11 (3x), vaksinasi GP-25 tiga kali seminggu; GP-25 (3x), kontrol negatif (tanpa tes KHV) dan kontrol positif (KHV diuji). Ikan disimpan selama 28 hari setelah vaksinasi dan kemudian dilanjutkan dengan uji tantangan KHV selama 28 hari. Berat ikan mas berkisar antara 13,82 $\pm 2,37 \mathrm{~g}$ dipelihara dengan kepadatan $15 \mathrm{ikan} /$ akuarium. Hasil penelitian menunjukkan bahwa pemberian vaksin mampu menginduksi respon imun seperti yang ditunjukkan oleh jumlah sel darah putih, aktivitas lisozim dan titer antibodi pasca-vaksinasi menunjukkan efek yang signifikan dibandingkan dengan kontrol. Demikian juga setelah uji tantang, didukung oleh parameter ekspresi gen IFNy dan IgM setelah uji tantang menunjukkan nilai tertinggi dari pemberian vaksin daripada kontrol. Kemanjuran vaksin ditunjukkan oleh nilai RPS (\%) pada setiap perlakuan vaksin yang diperoleh nilai GP-11 (1x) 44,7 \pm 3,7a, GP-11 (2x) 78,9 \pm 18,2b, GP-11 (3x) 85,6 $\pm 12.6 \mathrm{~b}$ dan GP-25 (3x) $79.5 \pm 18$.1b. Disimpulkan bahwa pemberian frekuensi vaksin GP-11 2 kali seminggu memberikan perlindungan yang sama kuatnya dengan memberikan frekuensi vaksin 3 kali seminggu.
\end{abstract}

Kata kunci: ikan mas, vaksin DNA, frekuensi pemberian, koi herpesvirus 


\section{Introduction}

Diseases caused by koi herpesvirus (KHV) infection are infectious viral diseases in carp and koi that cause significant mortality reaching 80 $100 \%$ of the population (Bergmann et al., 2010). Based on the latest found survey in 2018 at Situdaun Village, Bogor regency, KHV disease still attacks carp with mortality reached $20 \%$ in 7 days. KHV is mainly occurring at water temperatures between $18^{\circ} \mathrm{C}$ and $28^{\circ} \mathrm{C}$ (Gotesman et al., 2013). Acute infections occur at $22^{\circ} \mathrm{C}$ water temperatures which activate the virus resulting in clinical symptoms, tissue damage and death reached $75 \%$ in healthy fish that live together with infected fish (cohabitation) (Sunarto et al., 2014).

Viral diseases can be prevented by DNA vaccines, which can induce fish immunity against certain pathogens. DNA vaccines are genetic constructs containing one or more genes derived from pathogens and are designed to produce proteins from genes in vaccines to obtain a protective immune response (Biering and Salonius 2014). GP-11 KHV DNA vaccine was previously applied by injection and could protected against the KHV virus with RPS 93.33\% (Chairunnisa et al., 2016). GP-11 KHV DNA vaccine uses gene sequences that encode the open reading frame (ORF) glycoprotein 81 of an immunogenic KHV virus using a keratin promoter (Alimuddin et al., Personal communication). KHV DNA vaccine research through feed was previously reported by Nuryati et al., (2015) used GP-25 KHV DNA whole cell vaccine with a frequency of 3 times for 7 days resulted in RPS of $84 \%$. The GP-25 KHV DNA vaccine used gene sequences that encode the ORF 25 glycoprotein from an immunogenic KHV virus with a beta-actin promoter (Nuryati et al., 2010)

Another alternative is giving vaccines through feed (oral vaccination). Vaccination methods through feed have the advantage of being easy to give, reducing stress on fish, and suitable for mass vaccination at all ages of fish (Plant and Lapatra 2011). Therefore, in this study the application of the KHV GP-11 DNA vaccine through feed with different frequency of administration compared with the KHV GP-25 DNA vaccine.

\section{Materials and Methods}

\subsection{Fish, KHV DNA Plasmid, Virus}

Common carp were obtained from fish farmers in Situdaun Village, Bogor district. Fish weight ranges from $13.82 \pm 2.37$ g. E.coli $\mathrm{DH} 5 \alpha$ bacteria plasmid carrier GP-11 KHV DNA and
E.coli $\mathrm{DH} 5 \alpha$ bacteria plasmid carrier GP-25 KHV DNA. Viral isolates derived from common carp that were KHV positive after virulence.

\subsection{Vaccine Propagation}

The bacteria E.coli DH5a GP-11 plasmid carrier was cultured on 2XYT liquid media and incubated in a shaker incubator at $37^{\circ} \mathrm{C}$ at 200 rpm for 16-20 hours. Bacteria were harvested by centrifugation at $12000 \mathrm{rpm}$ for 30 seconds, then the pellets were washed with phosphate buffer saline (PBS) 2 times. Bacterial density was measured by Mc Farland. Bacterial cell density was made to $10^{8} \mathrm{cfu} / \mathrm{mL}$. Bacteria were inactivated by immersing them with water at 80 ${ }^{\circ} \mathrm{C}$ for 5 minutes. Whole cell vaccine of the GP$11 \mathrm{KHV}$ DNA plasmid carrier was then stored at $4{ }^{\circ} \mathrm{C}$ until used.

\subsection{Mixing the Vaccine with Feed}

The whole cell vaccine of GP-11 KHV DNAcarrying bacterium at a dose of $10^{8} \mathrm{cfu} / \mathrm{fish}$ (Nuryati et al., 2015) was mixed with egg white as a binder of $3 \%$ and water of $40 \%$ by feed weight and homogeneous. The mixture was poured into the treatment feed and then homogenized until it was evenly distributed in the feed. The feed mixture was left to dry at room temperature. Mixing the feed with the vaccine was done one day before giving the treatment feed. Control feed using only commercial feed.

\subsection{Vaccine administration and fish maintenance}

Vaccine feed consists of 4 treatments including : GP-11(1x) : GP-11 vaccine feed with a frequency of 1 dose a week, GP-11(2x): GP11 vaccine feed with a frequency of 2 doses a week, GP-11(3x): GP-11 vaccine feed with a frequency of 3 times a week dose and GP-25(3x) : GP-25 vaccine feed with a frequency of 3 times the dose a week. Feed was given per day by at satiation in the morning and evening. The number of fish vaccinated as many as 15 fish per treatment with 4 replications so that one treatment was 60 fish. There were also control treatments that were given commercial feed without vaccines. Vaccinated carp were then kept for 28 days in an aquarium $\left(60 \times 40 \times 40 \mathrm{~cm}^{3}\right)$ equipped with aeration. Water quality of maintenance media was maintained through $70 \%$ water changes every 5 days. The commercial feed used contains $28 \%$ protein content

\subsection{KHV Challenge Test}

The virus used came from KHV positive carp after virulence. Preparation of the virus filtrate was done by grinding 1 gram of gills using a sterile mortar and dissolved in $9 \mathrm{~mL}$ of cold 
PBS. The filtrate was centrifuged at a speed of $6500 \mathrm{rpm}$ for 10 minutes at $4{ }^{\circ} \mathrm{C}$. The supernatant was taken and filtered with a 0.45 $\mu \mathrm{m}$ syringe filter. The supernatant obtained was a stock of concentrations of $10^{-1}$. The challenge test was carried out on the 30th day after vaccination by injecting $0.1 \mathrm{~mL}$ KHV filtrate intramuscularly (i.m) in each vaccine treatment. Whereas the control treatment was divided into negative controls (without being tested) and positive controls (challenged with KHV). The fish after the challenge test was kept for 28 days at a permissive temperature of $\mathrm{KHV}\left(22^{\circ} \mathrm{C}\right)$ with an air conditioner (AC).

\subsection{Fish Blood and Serum Sampling}

Fish anesthetized with $1 \mathrm{~mL} / \mathrm{L}$ Ocean free special arowana stabilizer. A total of 3 fish for each treatment was taken blood up to $1 \mathrm{ml}$ (pooling sample) for the parameters of white blood cells, while lysozyme activity and antibody using fish serum. Fish serum sample were obtained from blood was taken without using anti-coagulant, then performed centrifugation and the obtained serum was stored in a freezer at a temperature of $-20^{\circ} \mathrm{C}$ until use it. Sampling for white blood cells, lysozyme activity, and antibody titer was carried out on day 7, 14 and 28 after vaccination and after challenge test.

\subsection{Parameter test}

\subsubsection{Survival Rate (SR)}

SR observation at the end of the study. SR calculation was done by the formula:

$\mathrm{SR}(\%)=\frac{\text { Number of final fish (Nt) }}{\text { Number of initial fish (N0) }} \times 100$

\subsubsection{Relative Percent Survival (RPS)}

RPS observation refered to Amend (1981) was observed at the end of the study.

RPS $(\%)=\left(1-\frac{\% \text { mortality in vaccinated fish }}{\% \text { mortality in control fish }}\right) \mathrm{x}$ 100

\subsubsection{White blood cell}

White blood cell counts were calculated according to the method of Anderson and Siwicki (1993):

$\sum$ Leukocytes $\left(\right.$ cells $\left./ \mathrm{mm}^{3}\right)=$ average $\Sigma$ counted cells $x \frac{1}{\text { large square volume }} \times$ dilution factor

\subsubsection{Lysozyme activity}

Lysozyme activity refers to Litwack (1955): Lisozyme Activity (Unit $/ \mathrm{mL})$ = initial OD-final OD x 1000

\section{final measurement time}

sample volume

\subsubsection{Antibody titer}

Antibody titer used the Enzyme Linked Immunosorbent Assay (ELISA) method adopted from Aonullah et al., (2016). Preparation of antigen for ELISA test was done by breaking KHV filtrate using sonicator at a frequency of 40 $\mathrm{Hz}$ for five minutes (on ice). Sonicated antigen was measured its protein concentration by Braddford method. Antigen was diluted 1:50 using coating buffer $(0.05 \mathrm{M}$ carbonatebicarbonate $\mathrm{pH}$ 9.5), so the final antigen concentration used was $5 \mu \mathrm{g} / \mathrm{mL}$. The diluted antigen was then inserted into each microplate well as much as $100 \mu \mathrm{L}$ and incubated at $4^{\circ} \mathrm{C}$ overnight. The next plate was rinsed five times using PBS-T (PBS pH 7.4 +of $0.05 \%$ Tween-20) as much as $300 \mu \mathrm{L}$ in each well. Each well on the test plate was blocked using PBS skim milk $5 \%$ as much as $100 \mu \mathrm{L}$ and incubated at $37^{\circ} \mathrm{C}$ for $2 \mathrm{~h}$. Plate was then rinsed with the same method as the previous step. Serum sample was diluted 1:50, then it was added into each well as much as $100 \mu \mathrm{L}$ and incubated at $37^{\circ} \mathrm{C}$ for $1 \mathrm{~h}$. The samples tests were conducted twice (duplicate). Plate was then washed with the same method as the previous step. Anti-carp IgG derived from rabbit was added as much as 100 $\mu \mathrm{L}$ into each well and incubated at $37^{\circ} \mathrm{C}$ for $1 \mathrm{~h}$. Plate was then washed with the same method as the previous step. Anti-rabit IgG conjugated with Horse Reddish Peroxydase (HRP) was added into each well as much as $100 \mu \mathrm{L}$ and incubated at $37^{\circ} \mathrm{C}$ for $1 \mathrm{~h}$. Plate was then washed with the same method as the previous step. One-Step Ultra TMB-ELISA was then added into each well as much as $100 \mu \mathrm{L}$ and let it being reacted for 20-30 $\mathrm{min}$. The reaction was stopped by adding $50 \mu \mathrm{L}_{2} \mathrm{SO}_{4} 3 \mathrm{M}$ and optical density (OD) reading was performed at $450 \mathrm{~nm}$.

\subsubsection{IFNy and IgM gene expression}

Analysis of gamma interferon (IFNY) and immunoglobulin $\mathrm{M}$ (IgM) gene expression was performed on day 14 after the challenge test. Samples from the front kidney (head kidney) were taken as much as $10-25 \mathrm{mg}$ and then the samples were stored at $-80^{\circ} \mathrm{C}$ until used for RNA extraction. Total RNA was extracted using GENEzol $^{\mathrm{TM}}$ reagent by the method according to the procedure in the manual. Total RNA was dissolved with $50 \mathrm{~mL}$ of nuclease-free water (NFW). The total RNA concentration was measured using GeneQuant. Complementary DNA synthesis (CDNA) was carried out using the ReverTrace qPCR RT Master Mix kit with gDNA Remover using manual procedures. The synthesis results were diluted by adding $50 \mu \mathrm{L}$ of nuclease-free water (NFW) and stored at $-20^{\circ} \mathrm{C}$ until use. The expression level of each gene from 
each sample was analyzed quantitatively using real-time PCR ( $\mathrm{PPCR}$ ) with the Rotor Gene machine (Corbett research) with the SensiFAST SYBR $\circledast$ No-ROX kit, and using specific primers. The amplification data recorded was processed by Livak and Schmittgen (2011) methods to calculate the level of gene expression, which was normalized using beta actin ( $\beta$-actin) as an internal control of RNA loading during cDNA synthesis.

\subsection{Statistical Analysis}

Data parameters for survival rates, relative survival rates, white blood cells, lysozyme activity, and antibody titers were tested with ANOVA using SPSS 16.0. Further test with Duncan. Meanwhile, data on gene expression levels were analyzed descriptively

\section{Results and Discussion}

GP-11 KHV DNA and GP-25 KHV DNA vaccines showed a protective impact in carp against KHV infection rather than control. This was shown in the results of the survival value of the vaccine treatment, which was higher than the positive control, where the SR value (Table 1) of the vaccine treatments were GP-11(1x) of $73.1 \%$, GP-11(2x) of $89.7 \%$, GP-11(3x) of $93 \%$ and GP-25(3x) of $90 \%$, differed significantly from positive controls of $51.3 \%$. This was consistent with several other DNA vaccine studies which also showed a high survival rate of $96.7 \%$ (Nuryati et al., 2010) 86-93\% (Chairunnisa et al., 2016); 68.89\% (Aonullah et al., 2016) compared with positive controls. Meanwhile the mortality value (Table 1) was inversely proportional to the $S R$ value. The highest mortality in the vaccines treatment was GP-11(1x) of $26.9 \%$ and the lowest was GP-11 (3x) of 7\%, while the positive control of $48.7 \%$. Vaccine efficacy could be seen from the RPS value, if the RPS value> $50 \%$ could be said that vaccine testing is effective (Ellis, 1988). Vaccine efficacy showed the RPS value (Table 1) was consistent with the $S R$ value, where GP-11(2x) treatment is $78.9 \%$, GP$11(3 x)$ of $85.6 \%$ and GP-25(3x) of $79.5 \%$ has RPS value which was not really different. This showed that the vaccine treatment with the frequency of administration twice and 3 times is equally strong in protecting against KHV infection. Vaccination with a frequency of once a week in the treatment of GP-11(1x) obtained an RPS value of $44.7 \%$, which showed the weak protection of the vaccine against KHV infection. This indicated the frequency of vaccine administration 2 times and 3 times stronger than 1 time the dose of vaccine administration. This was following Nuryati et al., (2015) stated that giving vaccines through feed with 3 times of administration for 1 week resulted in a high RPS of $84.6 \%$. The protective response was thought to be due to the persistence of DNA vaccine in the body was higher if the frequency of administration is higher. Reported by Nuryati et al., (2013) stated, DNA vaccine persistence in the body is higher given 2 times for one week rather than 1 time in one week. Other studies have also reported the frequency of giving DNA vaccines through feed more than once giving showed better protection, among others: the frequency of vaccination 3 times with an interval of 10 days (Shin et al., 2013) 4 times with intervals a week (Seo et al., 2013), 3 days followed by 2 boosters for 3 days after 8 days and 25 days after the first vaccine was given (Cui et al., 2015)

Table 1. Survial rate (SR), mortality and relative percent survival (RPS)

\begin{tabular}{cccc}
\hline \multirow{2}{*}{ Treatments } & \multicolumn{3}{c}{ Parameters } \\
\cline { 2 - 4 } & Mortality (\%) & SR $(\%)$ & RPS $(\%)$ \\
\hline GP-11(1x) & $26,9 \pm 1,8^{\mathrm{b}}$ & $73,1 \pm 1,8^{\mathrm{b}}$ & $44,7 \pm 3,7^{\mathrm{a}}$ \\
GP-11(2x) & $10,3 \pm 8,9^{\mathrm{c}}$ & $89,7 \pm 8,9^{\mathrm{c}}$ & $78,9 \pm 18,2^{\mathrm{b}}$ \\
GP-11(3x) & $7,0 \pm 6,1^{\mathrm{c}}$ & $93,0 \pm 6,1^{\mathrm{c}}$ & $85,6 \pm 12,6^{\mathrm{b}}$ \\
GP-25(3x) & $10,0 \pm 8,8^{\mathrm{c}}$ & $90,0 \pm 8,8^{\mathrm{c}}$ & $79,5 \pm 18,1^{\mathrm{b}}$ \\
Control - & $0,0 \pm 0,0^{\mathrm{c}}$ & $100,0 \pm 0,0^{\mathrm{c}}$ & \\
Control + & $48,7 \pm 16,8^{\mathrm{a}}$ & $51,3 \pm 16,8^{\mathrm{a}}$ &
\end{tabular}

Different superscript letters showed significantly different effects on the same parameters $(P<0,05)$ 
The application of DNA vaccines could induce non-specific celluler immune systems as indicated by the parameters of the number of white blood cells (Figure 1). All vaccine treatments showed significantly different results on negative controls on white blood cell observations on day 28. It was suspected that vaccines that enter the body provide stimulus to white blood cells to respond to incoming antigens by increasing the number of cells as an initial process of immune formation. Whereas day 7 and day 14 after vaccination were not significantly different from negative controls. Leukocytes total during day 7 challenge test were significantly different in the treatment of GP-25(3x) to positive control. When day 14 after the challenge test, treatment of GP-11(1x), GP$11(2 x)$ and GP-25(3x) showed significantly different results with positive control. This was caused by the presence of KHV infection that enters the body so that it was responded to by white blood cells by increasing the number, which was played by T lymphocytes as helper $T$ cells and cytotoxic $T$ cells that play a role in holding intracellular pathogenic infections and to kill cells infected with a virus. This was also supported by the parameters of gamma interferon gene expression levels (Figure 2) on day 14 after the challenge test, which treatment of GP-11(3x) has the highest value compared to other treatments including positive control. This was presumably because IFN gene expression responds to incoming pathogens by sending signals to activate macrophages and induce expression of MHC (major histocompatibility complex) class II molecules. Gamma interferon $(\mathrm{IFN} \gamma)$ is a cytokine that plays a role in natural and adaptive immunity when a viral infection occurs. Meanwhile, on day 28 after the challenge test of white blood cell, all treatments were not significantly different from negative controls. This showed the effect of KHV infection in the body has been reduced so that white blood cells did not multiply the cells. Reported of Gao et al., (2018) stated that white blood cells did not different significantly from controls when the test period was challenging with viruses.

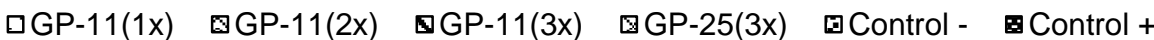

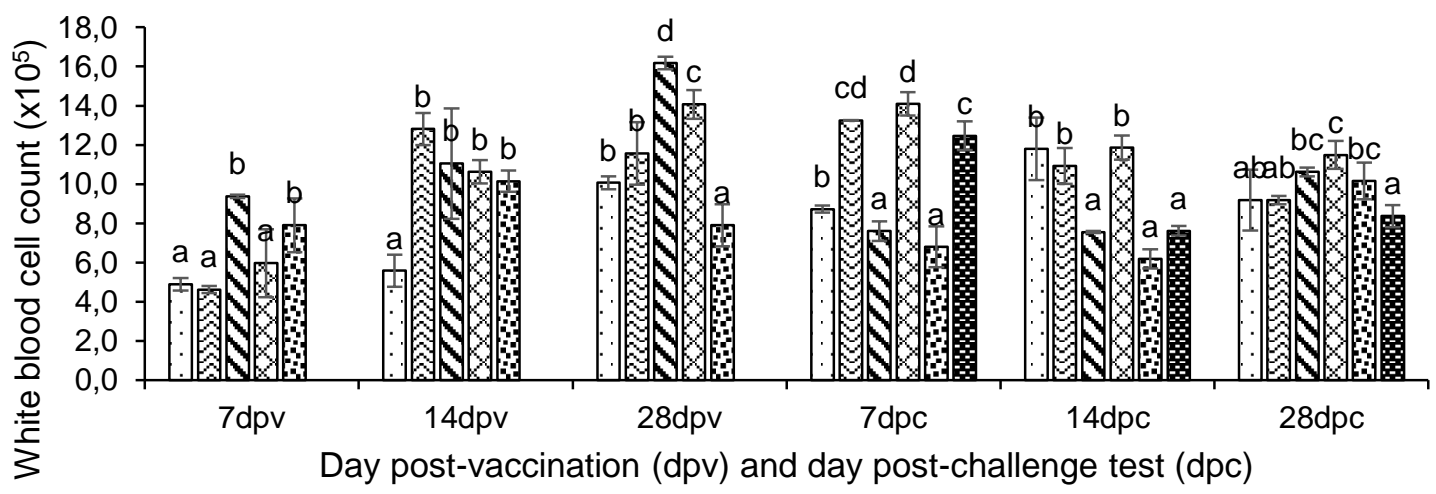

Figure 1. White blood cell count after vaccination and post-challenge test. The letters above the bar show significantly different effects on the same day $(\mathrm{P}<0.05)$

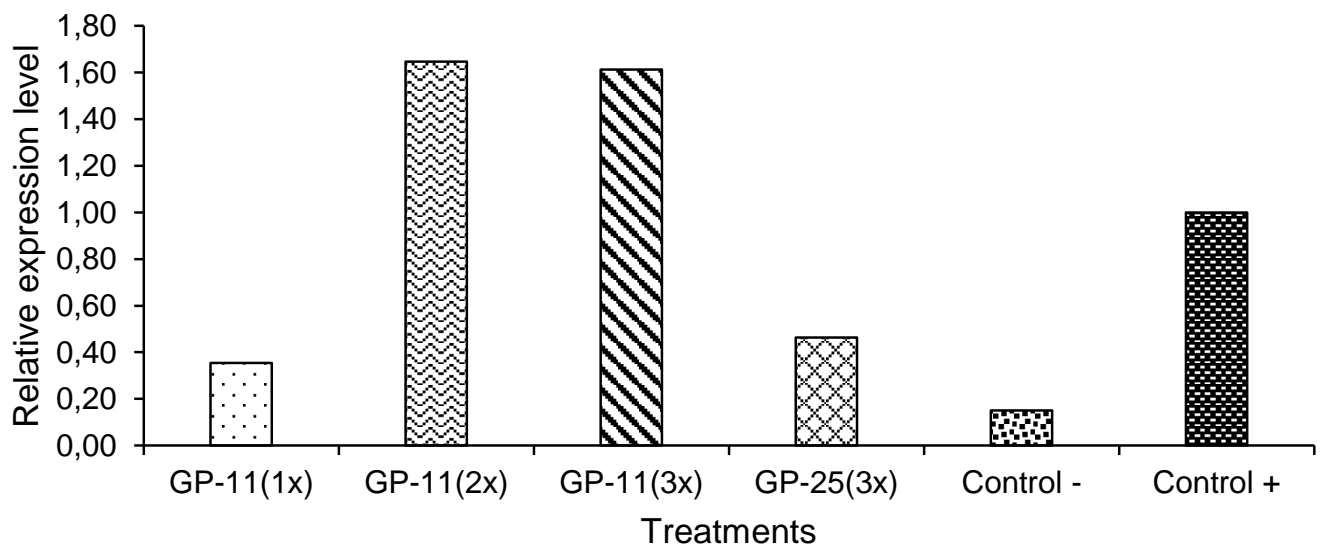

Figure 2. The level of IFNy gene expression on day 14 after the challenge test. The level of expression is relative to the positive control. 
Vaccination also showed the effect on nonspecific humoral immunity, which was shown by Lisozim activity. Lysozyme activity (Figure 3 ) on day 14 post-vaccination with a frequency of 2 times and 3 times had a significant effect, whereas on day 28 only the GP-25(3x) treatment was significantly different. Lysozyme activity from day 7 to day 28 tends to decrease in the treatment of GP-25(3x), which was significantly different from negative controls. Other studies have also reported lysozyme activity causing a significant increase in vaccine treatment when compared with controls (Kole et al., 2018; Skinner et al., 2010). Meanwhile, after the challenge test, the GP-25 (3x) treatment was significantly different from the other treatments on day 7 . While on day 14 and day 21 , the values of all treatments were not significantly different from the positive control and negative control. The value of lysozyme activity after the challenge test tended to decrease from day 7 after the challenge test until day 28. This was due to lysozyme working at the beginning when there was infection and inflammation. Lysozyme is known to be an opsonin and plays a role in the inflammatory response through activation of the complement system and phagocytosis, which during the process of inflammation, macrophages and polymorphonuclear granulocytes ingest and destroy pathogens that are recognized (Magnadottir, 2006).

Vaccine administration also showed a significant difference in the specific humoral immune system that was an antibody. The antibody values (Figure 4) on day 14 differed significantly in the GP-11(3x) treatment with a negative control. This was consistent with other reports which state, antibody titers begin to increase significantly on day 7 after vaccination and until the peak of day 28 (Gao et al., 2018). However, antibody values tended to increase slightly from day 7 to day 28 in the GP-11(3x) treatment. The formation of antibodies was the final response of the vaccination process to provide protection when an infection occurs by the same pathogen. Observation of antibodies after day 14 challenge test, GP-11(2x) treatment showed a significant effect with positive and negative controls. The same thing was also shown in the observation of the level of expression of the immunoglobulin M (IgM) gene (Figure 5), the treatment of GP-11(2x) and GP$11(3 \mathrm{x})$ showed a level of expression that was 2 times higher than the positive control. The IgM gene is a major component of the fish's humoral immune system, considered the first antibody (Tian et al., 2009). Some reports state that IgM gene expression significantly increases from day 7 to day 42 post-vaccination. (Gao et al., 2018). IgM gene expression levels have also been reported in vaccinated carp (grass cap) fish having higher levels of expression than controls when testing challenging grass carp reovirus (GCRV) (Pei et al., 2019). Some researchers have reported that the expression of adaptive immunity genes will increase intensively in many tissues and organs from the second week after immunization and be maintained for almost a month, which was consistent with antibody production results (Zhu et al., 2015; Medzhitov and Jr., 2016). This shows the treatment of vaccines can form antibodies, which antibodies work to eliminate viruses that have been previously identified so as not to cause infection to the body of the fish.

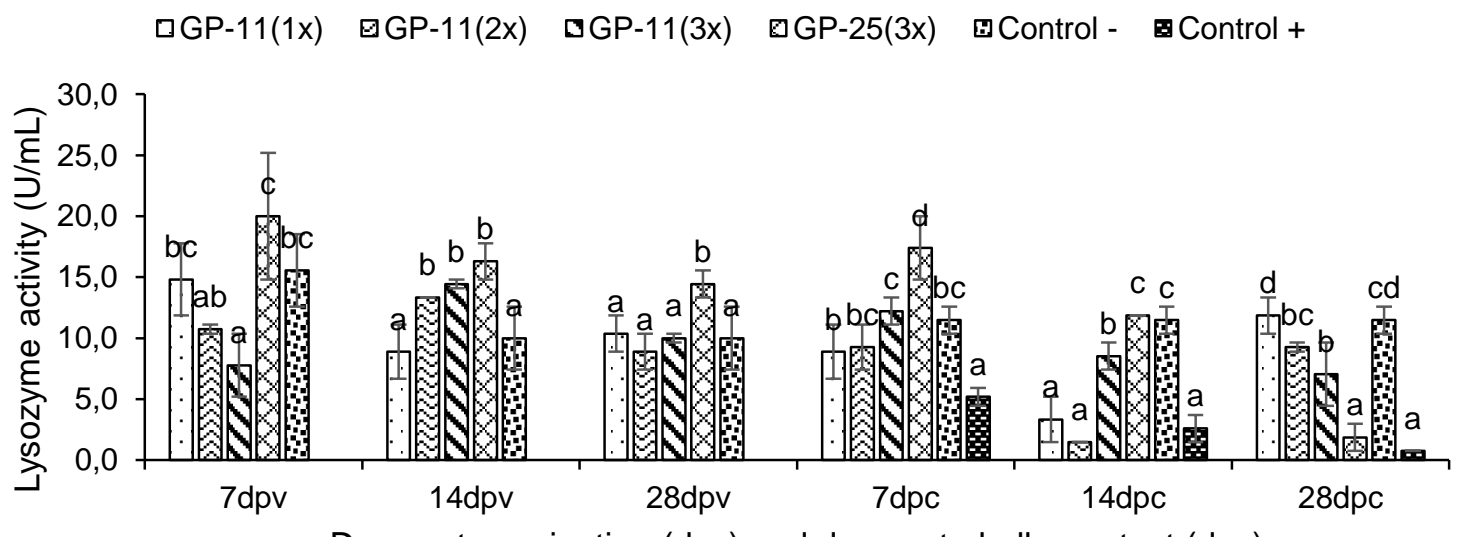

Day post-vaccination (dpv) and day post-challenge test (dpc)

Figure 3. Lysozyme activity after vaccination and post-challenge test. The letters above the bar show significantly different effects on the same day $(P<0.05)$. 
$\square \mathrm{GP}-11(1 \mathrm{x}) \quad \nabla \mathrm{GP}-11(2 \mathrm{x}) \quad \mathrm{GP}-11(3 \mathrm{x}) \quad \mathrm{GGP}-25(3 \mathrm{x}) \quad$ Control - $\mathbf{m}$ Control +

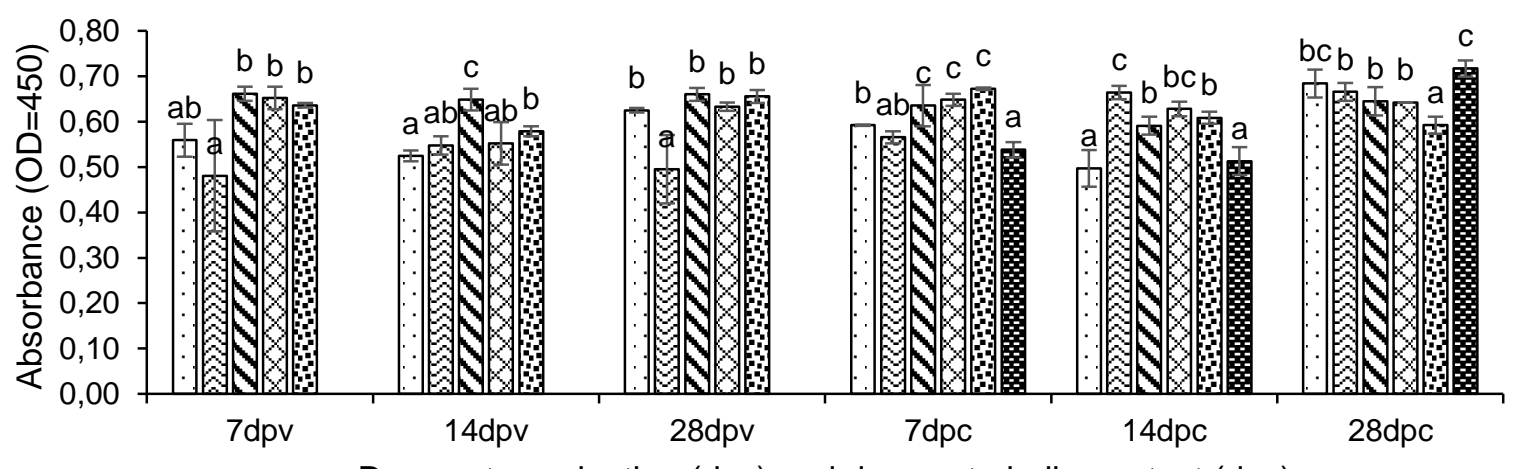

Day post-vaccination (dpv) and day post-challenge test (dpc)

Figure 4. Antibody titers after vaccination and challenge test. The letters above the bar show significantly different effects on the same day $(P<0.05)$.

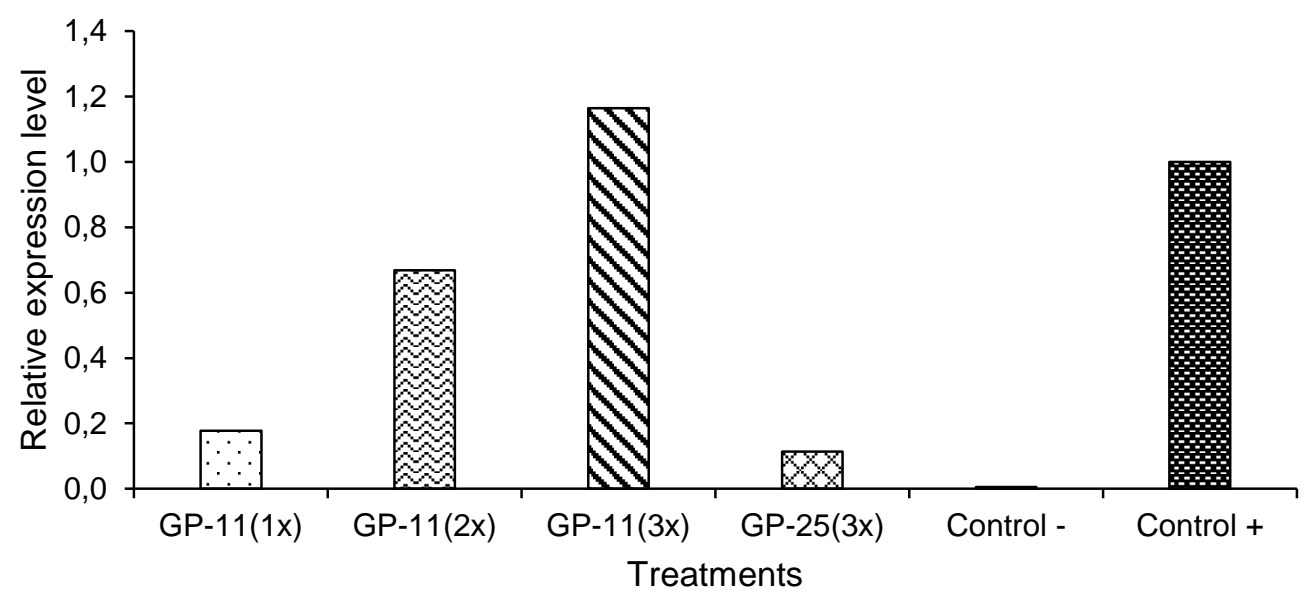

Figure 5. The level of IgM gene expression on day 14 after the challenge test. The level of expression was relative to the positive control.

One of the key factors in vaccine success through feed is the ability of the vaccine to pass through an acidic gastric environment without antigen degradation to reach the second intestinal segment in order to induce local and systemic responses (Munang'andu et al., 2015). Vaccines given through feed in this study proved that KHV DNA was able to be transcripted and translated into the body of fish through inactivated bacterial cells E.coli $\mathrm{DH} 5 \mathrm{a}$ as a carrier of plasmid GP-11 KHV DNA and GP-25 $\mathrm{KHV}$ DNA. This was possible because the inactivated bacteria E.coli could act as a natural barrier to the protection of the stomach and intestine environment without the need for encapsulation. Inactivated bacteria would be able to diffuse through the mucous layer and attach to intestinal epithelial cells (enterocytes) to be absorbed. Thus, inactivated bacteria provide inflammatory signals for local immune reactions due to the presence of pathogen associated molecular patterns (PAMPs) that trigger danger signals (Embregts et al., 2016). Several studies have reported successful use of inactivated and live attenuated bacteria as vector carriers of DNA vaccines, including: $E$. coli DH5a which was activated expresses the VP5-VP7 protein capsid from Grass Carp Reovirus (GCRV) (Lu et al., 2011), glycoprotein spring viremia of carp virus (SVCV) (Zhang et al., 2019) and S. agalactiae antigens (Nur-Nazifah et al., 2014). L. plantarum (L. plantarum) live expressing Spring Viremia Carp Virus (SVCV) or Cypinid Herpesvirus-3 antigen (CyHV-3) (Cui et al., 2015), S. typhimurium live expressing immunogenic proteins from $S$. agalactiae (Huang et al., 2014) and live Lactococcus lactis express Aeromonas hydrophila antigens (Anuradha et al., 2010).

DNA vaccines expressing antigens in the form of KHV glycoproteins that successfully enter the intestine will be absorbed by enterocyte 
cells (Chen et al., 2015; Joosten et al., 1997). Antigen absorption occurs in the second segment of the intestine, where the second segment of the intestine has a proportion of 10 $15 \%$ of the length of the intestine (Rombout et al., 2014). The local immune response in the intestine is played by gut-associated lymphoid tissue (GALT) which can activate immunerelated genes (Rombout et al., 2014) and produce local antibodies (Anuradha et al., 2010; Siriyappagouder et al., 2014). Oral administration of antigens also resultsed in stimulation of the mucosal and systemic responses (Chen et al., 2014; Xue et al., 2013) which are symbolized by $\operatorname{lgM}$ circulation (Mutoloki et al., 2015). KHV glycoproteins woul be considered as antigens so that the body signals the non-specific immune system as a sign of foreign substances. These antigens are then presented by antigen presenting cells (APCs), namely macrophages or dendritic cells (Aoki et al., 2011), then form complexes on the surface of major class histocompatibility complex (MHC) class I and MHC class II (Rice et al., 2008). MHC I presents antigens to cytotoxic $\mathrm{T}$ cells $(\mathrm{CD} 8+)$ with intermediate receptor $\mathrm{T}$ cells. Cytotoxic $\mathrm{T}$ cells will act as destroyers of cells infected with antigens, so that when testing the KHV virus, cytotoxic cells will act quickly against infected cells to clear the virus, causing apoptosis (programmed cell death) (Nakanishi et al., 2011; Adamek et al., 2014). Meanwhile, MHC II presents antigens to helper T cells $(C D 4+)$ with intermediate receptor $\mathrm{T}$ cells. Helper $\mathrm{T}$ cells then play a role in the process of differentiated $B$ cells into plasma cells to produce specific antibodies and memory cells to record the type of antigen and recall when similar antigens enter (Coban et al., 2008; Stevenson et al., 2010), so that when challenged $\mathrm{KHV}$, antibodies that are formed will recognize the KHV virus that enters the body and play a role in neutralizing the virus so that it does not cause death in fish.

\section{Conclusion}

The application of KHV GP-11 DNA vaccine through feed with a frequency of 2 times the dose has the same efficacy as the treatment of the KHV GP-11 DNA vaccine frequency 3 times and the KHV DNA GP-25 frequency vaccine 3 times, in protecting against $\mathrm{KHV}$ infection.

\section{References}

Adamek M, Steinhagen D, Irnazarow I, Hikima J, Jung T-S, Aoki T. 2014. Biology and host response to Cyprinid herpesvirus 3 infection in common carp. Developmental and Comparative Immunology. 43(2): 151159.

Amend DF. 1981. Potency testing of fish vaccines. International Symposium on Fish Biologics: Serodiagnostics and Vaccines. Developments in Biological Standardization. 49:447-454.

Anderson DP, Siwicki AK. 1993. Basic hematology and serology for fish health programs. Paper Presented in Second Symposium on Diseases in Asia Aquaculture "Aquatic Animal Health and The Environmental". Phuket Thailand. 2529th October 1993.

Anuradha K, Foo HL, Mariana NS, Loh TC, Yusoff K, Hassan MD, Sasan H, Raha AR. 2010. Live recombinant Lactococcus lactis vaccine expressing aerolysin genes $D 1$ and D4 for protection against Aeromonas hydrophila in tilapia (Oreochromis niloticus). Journal of Applied Microbiology. 109(5):1632-1642.

Aoki T, Hikima J, del Castillo CS, Jung TS, Kondo H, Hirono I. 2011. Molecular immunity in the interaction between fish and pathogen for DNA vaccine. HIm. 253-268. Di dalam: Bondad-Reantaso, M.G., Jones, J.B., Corsin, F. and Aoki, T, editor. Diseases in Asian Aquaculture VII. Fish Health Section, Asian Fisheries Society, Selangor, Malaysia. HIm. 385.

Aonullah AA, Nuryati S, Alimuddin, Murtini S. 2016. Efficacy of koi herpesvirus DNA vaccine administration by immersion method on Cyprinus carpio field scale culture. Aquaculture Research. 1-8.

Bergmann SM, Lutze P, Schutze H, Fischer U, Dauber M, Fichtner D, Kempter J. 2010. Goldfish (Carassius auratus) is a susceptible species for koi herpesvirus (KHV) but not for KHV disease. BulletinEuropean Association of Fish Pathologists. 30:74-84.

Biering E, Salonius K. 2014. DNA vaccines. in: Gudding R, Lillehaug A, Evensen O, editor. Fish Vaccination 1st ed. John Wiley \& Sons, Ltd.

Chairunnisa SA, Nuryati S, Alimuddin, Murtini S, Santika A, Yanti DH. 2016. Efficacy of GP$11 \mathrm{KHV}$ DNA vaccine in Cyprinus carpio haematopterus. Journal of Indonesian Aquaculture. 11:31-39.

Chen L, Evensen $\varnothing$, Mutoloki S. 2015. IPNV antigen uptake and distribution in Atlantic 
salmon following oral administration. Viruses. 7(5):2507-2517.

Chen L, Klaric G, Wadsworth S, Jayasinghe S, Kuo T-Y, Evensen Ø, Mutoloki S. 2014. Augmentation of the antibody response of atlantic salmon by oral administration of alginate-encapsulated IPNV Antigens. PLOS ONE. 9(10).

Coban C, Koyama S, Takeshita F, Akira S, Ishii KJ. 2008. Molecular and cellular mechanisms of DNA vaccines. Humam Vaccines. 4(6):453-456.

Cui L-C, Guan X-T, Liu Z-M, Tian C-Y, Xu Y-G. 2015. Recombinant lactobacillus expressing $G$ protein of spring viremia of carp virus (SVCV) combined with ORF81 protein of koi herpesvirus (KHV): a promising way to induce protective immunity against SVCV and KHV infection in cyprinid fish via oral vaccination. Vaccine. 33(27):3092-3099.

Ellis A.E., 1988. Fish Vaccination. Academic Press, New York.

Embregts CWE, Forlenza M. 2016. Oral vaccination of fish: Lessons from humans and veterinary species. Developmental and Comparative Immunology. 64: 118-137.

Gao Y, Pei C, Sun X, Zhang C, Li L, Kong X. 2018. Plasmid pcDNA3.1-s11 constructed based on the S11 segment of grass carp reovirus as DNA vaccine provides immune Protection. Vaccine. 36(25):3613-3621.

Gotesman M, Kattlun J, Bergmann SM, EIMatbouli M. 2013. CyHV-3: The third cyprinid herpesvirus. Diseases of Aquatic Organisms. 105(2):163-174.

Huang LY, Wang KY, Xiao D, Chen DF, Geng Y, Wang J, He Y, Wang EL, Huang, JL, Xiao GY. 2014. Safety and immunogenicity of an oral DNA vaccine encoding Sip of Streptococcus agalactiae from Nile tilapia (Oreochromis niloticus) delivered by live attenuated Salmonella typhimurium. Fish and Shellfish Immunology. 38(1):34-41.

Joosten PH, Engelsma MY, van der Zee MD, Rombout JH. 1997. Induction of oral tolerance in carp (Cyprinus carpio L.) after feeding protein antigens. Veterinary Immunology and Immunopathology. 60(12):187-196.

Kole S, Kumari R, Anand D, Kumar S, Sharma R, Tripathi G, Makesh M, Rajendran KV, Bedekar MK. 2018. Nanoconjugation of bicistronic DNA vaccine against
Edwardsiella tarda using chitosan nanoparticles: Evaluation of its protective efficacy and immune modulatory effects in Labeo rohita vaccinated by different delivery routes. Vaccine. 36(16): 21552165.

Litwack G. 1955. Photometric determination of lysozyme activity. Proceedings for the Society for Experimental Biology and Medicine.89:401-3.

Livak KJ, Schmittgen TD. 2001. Analysis of relative gene expression data using realtime quantitative PCR and the 2- $\Delta \Delta \mathrm{CT}$ method. Methods 25: 402-408.

Lu L, Xu H, He Y, Li, J. 2011. Protection of grass carp, Ctenopharyngon idellus (Valenciennes), through oral administration of a subunit vaccine against reovirus. Journal of Fish Disease. 34(12):939-942.

Magnadottir B. 2006. Innate immunity of fish (overview). Fish and Shellfish Immunology. 20:137-51.

Medzhitov R, Jr J.C., 2016. Innate immune recognition and control of adaptive immune responses. Seminars in Immunology. 10(5):351-353.

Munang'andu HM, Mutoloki S, Evensen $\varnothing$. 2015. An overview of challenges limiting the design of protective mucosal vaccines for finfish. Review. Frontiers in Immunology. 6:542.

Mutoloki S, Munang'andu HM, Evensen $\varnothing$. 2015. Oral vaccination of fish-antigen preparations, uptake, and immune induction. Frontiers in Immunology. 6:519.

Nakanishi T, Toda H, Shibasaki Y, Somamoto T. 2011. Cytotoxic T cells in teleost fish. Developmental and Comparative Immunology. 35(12):1317-1323.

Nur-Nazifah, M., Sabri, M.Y., Siti-Zahrah, A., 2014. Development and efficacy of feedbased recombinant vaccine encoding the cell wall surface anchor family protein of Streptococcus agalactiae against streptococcosis in Oreochromis sp. Fish and Shellfish Immunology. 37(1):193-200.

Nuryati S, Alimuddin, Sukenda, Soejoedono RD, Santika A, Pasaribu FH, Sumantadinata K. 2010. Construction of a DNA Vaccine using glycoprotein gene and its expression towards increasing survival rate of KHVInfected common carp Cyprinus carpio. Jurnal Natur Indonesia.13: 47-52. 
Nuryati S, Khodijah S, Alimuddin, Setiawati M. 2015. Effectiveness of DNA vaccine in feed to koi herpesvirus-infected common carp. Jurnal Kedokteran Hewan. 9:33-37.

Nuryati S, Yulianti, Alimuddin. 2013. Frekuensi dan persistensi vaksin DNA penyandi GP25 yang diberikan melalui pakan pada ikan mas. Jurnal Akuakultur Indonesia. 12(2): 150-157.

Pei C, Gao Y, Sun X, Li L, Kong X. 2019. A developed subunit vaccine based on fiber protein VP56 of grass cap reovirus providing immune protection against grass carp hemorrhagic disease. Fish and Shellfish Immunology. 90:12-19.

Plant KP and Lapatra SE. 2011. Advances in fish vaccine delivery. Developmental and Comparative Immunology. 35:1256-1262.

Rice J, Ottensmeier CH, Stevenson FK. 2008. DNA vaccines: precision tools for activating effective immunity against cancer. Nature Reviews Cancer. 8(2):108-120.

Rombout JHWM, Kiron V. 2014. Mucosal vaccination of fish. Di dalam: Gudding $R$, Lillehaug A, Evensen $\mathrm{O}$, editor. Fish Vaccination. Oxford: Willey Blackwell. hlm. 56-67.

Seo JY, Chung HJ, Kim TJ. 2013. Codonoptimized expression of fish iridovirus capsid protein in yeast and its application as an oral vaccine candidate. Journal of Fish Disease. 36(9):763-768.

Shin YJ, Kwon TH, Seo JY, Kim TJ. 2013. Oral immunization of fish against iridovirus infection using recombinant antigen produced from rice callus. Vaccine. 31(45):5210-5215.

Siriyappagouder $\mathrm{P}$, Shankar KM, Naveen Kumar BT, Patil R, Byadgi OV. 2014. Evaluation of biofilm of Aeromonas hydrophila for oral vaccination of Channa striatus. Fish and Shellfish Immunology, 41(2):581-585.
Skinner LA, LaPatra SE, Adams A, Thompson KD, Balfry SK, McKinley RS. Schulte PM. 2010. Concurrent injection of a rhabdovirus-specific DNA vaccine with a polyvalent, oil-adjuvanted vaccine delays the specific anti-viral immune respons in Atlantic salmon (Salmo salar L.). Fish and Shellfish Immunology. 28(4):579-586.

Stevenson FK, Ottensmeier CH, Rice J. 2010. DNA vaccines against cancer come of age. Current Opinion in Immunology. 22(2):264270.

Sunarto A, McColla KA, Crane MSJ, Schat KA, Slobedman B, Barnes AC, Walker PJ. 2014. Characteristics of cyprinid herpesvirus 3 in different phases of infection: Implications for disease transmission and control. Virus Research. 188: 45-53.

Tian JY, Sun BJ, Luo YP, Zhang YG, Nie P. 2009. Distribution of $\lg M, \lg D$ and $\lg Z$ in mandarin fish, Siniperca chuatsi lymphoid tissues and their transcriptional changes after Flavobacterium columnare stimulation. Aquaculture. 288(1-2):14-21.

Xue R, Liu L, Cao G, Xu S, Li J, Zou Y. 2013. Oral vaccination of BacFish-vp6 against grass carp reovirus evoking antibody response in grass carp. Fish and Shellfish Immunology. 34(1):348-355.

Zhang C, Zhao Z, Li J, Song K-G, Hao K, Wang J, Wang GX, Zhu B. 2019. Bacterial ghost as delivery vehicles loaded with DNA vaccine induce significant and specific immune responses in common carp against spring viremia of carp virus. Aquaculture. 504:361-368.

Zhu B, Liu GL, Gong YX, Ling F, Wang GX. 2015. Protective immunity of grass carp immunized with DNA vaccine encoding the vp7 gene of grass carp reovirus using carbon nanotubes as a carrier molecule. Fish and Shellfish Immunology. 42(2):325334. 